\title{
A laboratory scale bioremediation of Tapis crude oil contaminated soil by bioaugmentation of Acinetobacter baumannii T30C
}

\author{
Lee Kok Chang ${ }^{1 \star}$, Darah Ibrahim ${ }^{1}$ and Ibrahim Che Omar \\ ${ }^{1}$ Industrial Biotechnology Research Laboratory (IBRL), School of Biological Sciences, Universiti Sains Malaysia, \\ 11800 Minden, Penang Malaysia. \\ ${ }^{2}$ Faculty of Agro Industry and Natural Resources, Universiti Malaysia Kelantan, Karung Berkunci 36, \\ 16100 Pengkalan Chepa, Kelantan, Malaysia.
}

Accepted 30 July, 2011

\begin{abstract}
Microbial degradation of Tapis crude oil contaminated soil by Acinetobacter baumannii T30C was conducted to evaluate the efficiency of the selected potential hydrocarbon degrader in stimulating bioremediation of crude oil-contaminated soil with different treatment units in microcosms with $2.5 \mathrm{~kg}$ soil. Previously, A. baumannii T30C was isolated from a Tapis crude oil-contaminated soil of oil refinery plant, Terengganu, Malaysia. The reduction of residual hydrocarbons in the soil was observed for a period of about 35 days. The study showed that amendment of nutrients was needed for stimulating the growth of $A$. baumannii T30C and indigenous microorganism in assisting the degradation of residual hydrocarbons in the soil.
\end{abstract}

Key words: Bioremediation, bioaugmentation, aliphatic hydrocarbons, amendment of nutrients.

\section{INTRODUCTION}

Environmental damage due to the oil spills in the past and recent time has focused on the need for the environment friendly strategies for remediation of the contaminated site. For instance, contamination of the environment with crude oil results in pollution, in particular presents a chronic problem to commercial fisheries, recreational resources and public health. Bioremediation is suggested for remediation of contaminated soil sites because of its low cost and its ability to convert contaminants to harmless end products (Rahman et al., 2002; Sathishkumar et al., 2008).

Other physical and chemical processes have been used to remove spilled oil from environment; however the use of these technologies has not always been successful (Aldrett et al., 1997). Bioremediation, the use of microorganisms or microbial process to degrade environmental contaminants is among these technologies (Boopathy, 2000). Numerous microorganisms, including

*Corresponding author. E-mail: leekokchang81@yahoo.com. Tel: +60123948310 . Fax: +6046565125 bacteria, fungi, and yeasts are known for their ability to degrade hydrocarbons (Swannell and Head, 1994). Recently, bioaugmentation which involves the addition of microorganisms to enhance specific biological activity has been applied in attempts to remediate numerous environmental problems (Vogel, 1996). The potential of using microorganisms for degradation of crude oil and its constituents to minimize contamination have prompted a number of researchers to study the process in laboratories. For instance, augmenting the contaminated site with appropriate bacterial inoculum is a promising technique to enhance the biodegradation of hydrocarbons. The aim of this study is to evaluate the efficiency of $A$. baumannii T30C in the remediation of Tapis crude oil-contaminated soil to degrade petroleum hydrocarbons.

\section{MATERIALS AND METHODS}

Bacterial culture and maintenance

The strain of $A$. baumannii T30C was isolated from the crude oil contaminated soil in Terengganu, Malaysia, and maintained on 
Nutrient Agar slant. The subculture was done every month to maintain its survival.

\section{Soil preparation}

The soil selected for this study had approximately six years of exposure to petroleum Tapis crude oil in Terengganu, Malaysia. The crude oil contaminated soil together with some of its physicochemical characteristic information was provided by Petronas Research Sdn. Bhd., Malaysia.

\section{Inoculum preparation}

In order to obtain a standard inoculum, a bacterial isolate $A$. baumannii T30C was grown in nutrient broth (NB) at $37^{\circ} \mathrm{C}$ in an orbital shaker at $200 \mathrm{rpm}$ to yield an absorbance reading of 0.5 at $600 \mathrm{~nm}$. The cells were harvested by centrifugation, rinsed with sterile distilled water before being re-suspended in sterile mineral salt medium (MSM), which consisted of $\left(\mathrm{NH}_{4}\right)_{2} \mathrm{SO}_{4}, 3 \mathrm{~g} ; \mathrm{KH}_{2} \mathrm{PO}_{4}, 4$ g; $\mathrm{Na}_{2} \mathrm{HPO}_{4}, 7 \mathrm{~g} ; \mathrm{MgSO}_{4} \cdot 7 \mathrm{H}_{2} \mathrm{O}, 0.2 \mathrm{~g} ; \mathrm{CaCl}_{2} \cdot 2 \mathrm{H}_{2} \mathrm{O}, 0.001 \mathrm{~g}$; $\mathrm{FeSO}_{4} \cdot 7 \mathrm{H}_{2} \mathrm{O}, 0.001 \mathrm{~g}$; Tween $80,4.0 \mathrm{~g} / \mathrm{L}$ in $1 \mathrm{~L}$ of distilled water. When used as an inoculum at $10 \%(\mathrm{v} / \mathrm{w})$, the resulting colony forming unit (CFUs/g) was approximately $1 \times 10^{7} \mathrm{CFUs} / \mathrm{g}$ of soil.

\section{Biodegradation experiments}

The ability of bacterial isolate to remediate the petroleum crude oil contaminated soil sample was performed by carrying out the biodegradation experiment in soil for 35 days under room temperature $\left(30 \pm 3^{\circ} \mathrm{C}\right)$. The experiments were carried out in rectangular aluminium trays of $30 \mathrm{~cm} \times 21 \mathrm{~cm} \times 6 \mathrm{~cm}$ (Length $\times$ Width $\times$ Height) containing $2.5 \mathrm{~kg}$ soil. Prior to starting the experiment, the water-holding capacity $(\mathrm{WHC})$ and $\mathrm{pH}$ of the soil were determined according to Alef and Nannipieri (1995). Determination of WHC of soil is based on the calculation as follows:

$\%$ Water-holding capacity $=\left[\left(100-W_{p}\right)+W_{i}\right] / d w t \times 100$

where; $W_{p}$ is the weight of the percolated water in grams, $W_{i}$ is the initial amount of water in grams contained in the sample, and $d w t$ is the soil dry weight in grams.

Experiments were conducted with the following treatment combinations:

Treatment A: Soil + bacterial isolate + nutrients

Treatment B: Soil + nutrients

Treatment C: Soil + bacterial isolate

Treatment D: Soil + sterile distilled water (abiotic control)

For each experimental unit, $10 \%(\mathrm{v} / \mathrm{w})$ of bacterial inoculum which made up of approximately $1 \times 10^{7}$ colony forming units (CFUs)/g of soil and nutrients from optimized MSM were seeded by maintaining the moisture level of $60 \%$ WHC of soil. Initial pH of the soil ranged from $\mathrm{pH} 6.0$ to $\mathrm{pH}$ 7.0. The trays were covered with sterile aluminium foil. The contents of the trays were mixed thoroughly every alternate day to provide adequate aeration. Every five days, the samples were taken out from the respective experimental unit and analyzed for viable cell count and the extent of biodegradation was determined. The bacterial counts in different treatment units were determined with standard dilution plating technique using sterile nutrient agar and the colony forming units were counted after 24 to $48 \mathrm{~h}$ of incubation at $37^{\circ} \mathrm{C}$. The extent of biodegradation was determined by extracting the extractable hydrocarbons according to the method described previously by Mishra et al. (2001a) and Das and Mukherjee (2007). Total petroleum hydrocarbon (TPH) was extracted from $10 \mathrm{~g}$ of soil by sequentially extraction with $100 \mathrm{ml}$ of hexane, dichloromethane and chloroform. All the three extracts were pooled and dried at a rotary evaporator (LABOROTA 4000, Heidolph, UK). All determinations were carried out in triplicates. After drying, the amount of extractable hydrocarbon was determined gravimetrically.

\section{Gas chromatographic analysis}

For analysis of crude oil sample, dodecane (Fluka Chemika) was used as an internal standard and O-terphenyl was used as a surrogate standard (Aldrich, USA). Calibration standards at 7 concentration levels were prepared at a range of 0.2 to $1.4 \mu \mathrm{g} / \mu \mathrm{l}$, respectively. Before extraction, O-terphenyl was added to each sample as surrogate standard to give a final concentration of 1.0 $\mu \mathrm{g} / \mu \mathrm{l}$ for calculating the efficiency of recovery. The internal standard with the final concentration of $0.7 \mu \mathrm{g} / \mu \mathrm{l}$ was used for quantitative purposes and checking the deviation from injection error.

The analysis for aliphatic hydrocarbons was performed on a Perkin Elmer Clarus 500 gas chromatograph equipped with a flame-ionization detector (FID). A high-temperature capillary column (DB-5HT, $30 \mathrm{~m} \times 0.32 \mathrm{~mm}$ i.d., $0.1 \mu \mathrm{m}$ film thickness; J\&W Scientific) was used. The carrier gas was helium $(2.5 \mathrm{ml} / \mathrm{min})$. The injector and detector temperatures used were set at 290 and $300^{\circ} \mathrm{C}$, respectively. The following temperature program was used: 2 min hold at $50^{\circ} \mathrm{C}$; ramp to $300^{\circ} \mathrm{C}$ at $6{ }^{\circ} \mathrm{C} / \mathrm{min}$; and $16 \mathrm{~min}$ hold at $300^{\circ} \mathrm{C}$. One microliter aliquot was injected in the split less mode with a 1 minute purge-off. This method was according to Wang et al. (1994). The overall percentage of oil biodegradation was determined from the chromatogram by calculating the average of peak height area of each compound on the chromatogram of a biodegraded sample to the control sample.

\section{RESULTS}

Initial residual hydrocarbons concentration in the soil was around $4200 \mathrm{mg} / \mathrm{kg}$ of soil as determined by gravimetric analysis. Figure 1 shows the profile of viable cell count of augmented $A$. baumannii T30C in different treatment of crude oil contaminated soil. Treatment $D$ refers to the control soil sample which was not amended with any addition of bacterial inoculum or nutrient showed a viable cell count of $2.29 \times 10^{3}$ CFUs/g of soil on the first day of inoculation. The bacterial cell numbers continued to increase after 10 days of inoculation. Then, the numbers decreased until 15 days of incubation and remained at viable cell count of approximately $1.55 \times 10^{5} \mathrm{CFUs} / \mathrm{g}$ of soil until the study was terminated. For Treatment $A$ and Treatment $B$, the initial viable cell counts were $2.19 \times 10^{7}$ CFUs/g of soil and $3.24 \times 10^{4} \mathrm{CFUs} / \mathrm{g}$ of soil, respectively. Treatment $A$ with the addition of bacterial inoculum and nutrient showed slightly increment of viable cell count of $2.23 \times 10^{8} \mathrm{CFUs} / \mathrm{g}$ of soil after 5 days of incubation. Then, the viable cell count decreased slightly to $1.29 \times 10^{8}$ $\mathrm{CFUs} / \mathrm{g}$ of soil until the end of the incubation period. For Treatment B which was added with nutrient, the results showed the effect of treatment to stimulate the growth of the indigenous microbial population. The viable cell count was dramatically increased to $4.17 \times 10^{8} \mathrm{CFUs} / \mathrm{g}$ of soil after 5 days of incubation. The viable cell count was 


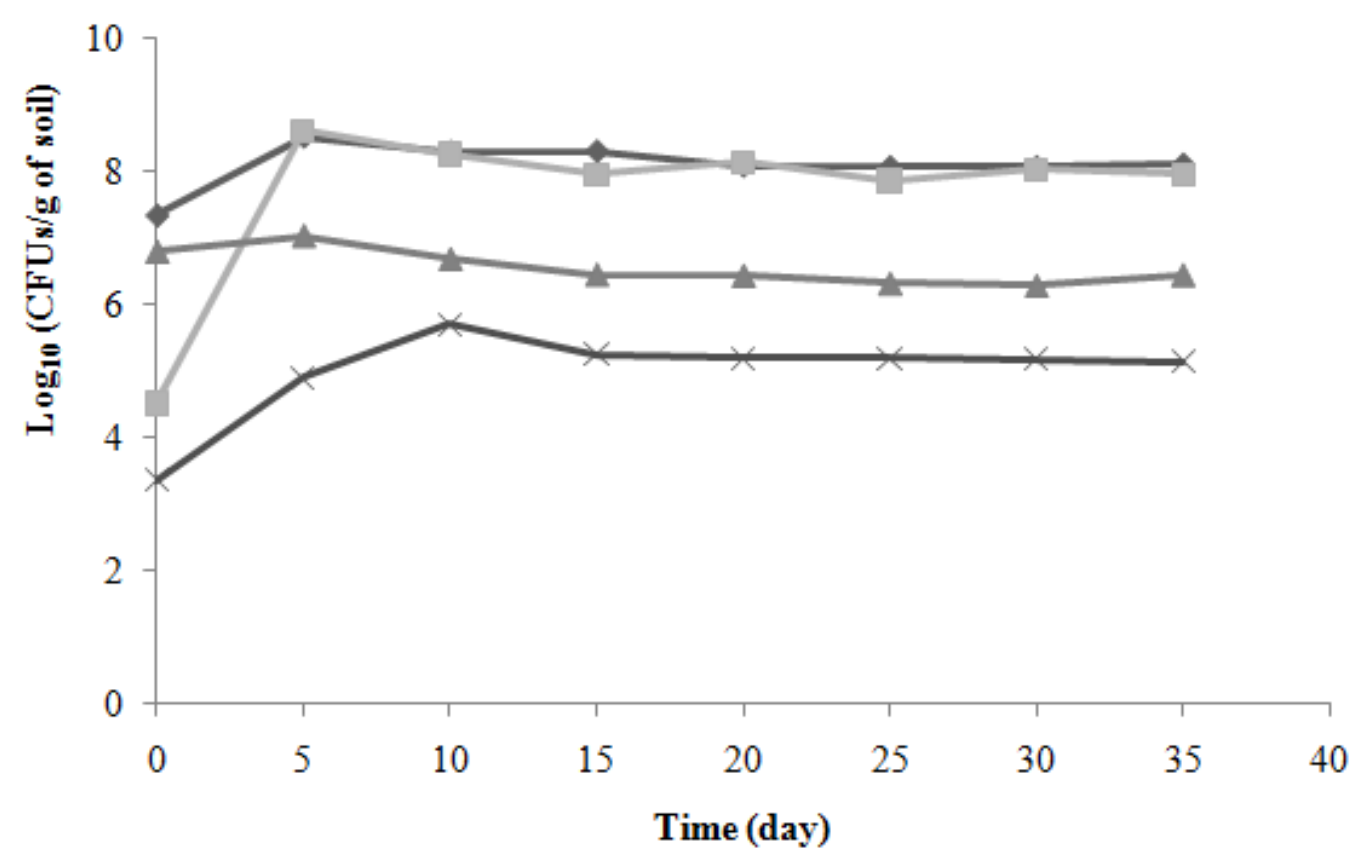

$\leadsto$ Treatment A $\rightarrow$ Treatment B $\leftarrow$ Treatment $\mathrm{C} \leadsto$ Treatment D

Figure 1. Profile of viable cell count in different treatment of crude oil contaminated soil. For each experimental unit, $10 \%(\mathrm{v} / \mathrm{w})$ of bacterial inoculum which made up of approximately $1 \times 10^{7}$ colony forming units (cfus) $/ \mathrm{g}$ of soil and nutrients from optimized MSM were seeded by maintaining the moisture level of $60 \%$ water holding capacity (WHC) of soil. Treatment A: Soil + bacterial isolate + nutrients; Treatment B: Soil + nutrients; Treatment C: Soil + bacterial isolate; Treatment D: Soil + sterile distilled water (abiotic control).

decreasing after that and achieved about $9.12 \times 10^{7}$ CFUs/g of soil at the end of the experiment (35 days). Treatment $A$ and Treatment $B$ showed almost the same amount of reduction in residual hydrocarbons concomitantly by the end of the 35 days of treatment, which decreased to around $2605 \mathrm{mg} / \mathrm{kg}(42 \%)$ and $2423 \mathrm{mg} / \mathrm{kg}$ $(43 \%)$, respectively (Figure 2). Thereby, it was established that the augmentation of $A$. baumannii T30C into the soil was not playing a part in reduction of residual hydrocarbons. This was supported by the result of Treatment $C$ in which only bacterial isolate T30C was augmented without the addition of nutrient in the oil contaminated soil. Results showed that there was a delay in the reduction of residual hydrocarbons and limitation of bacteria to consume the contaminant in the soil without amendment of nutrient. For Treatment $\mathrm{C}$, the residual hydrocarbons decreased to $3448 \mathrm{mg} / \mathrm{kg}$, which was approximately $15 \%$ of degradation. The viable cell count decreased from $6.31 \times 10^{6} \mathrm{CFUs} / \mathrm{g}$ of soil to $2.82 \times 10^{6}$ CFUs/g of soil. Amendment of nutrients was needed for stimulating the growth of bacteria and assisting the degradation of residual hydrocarbons in the soil. Treatment $D$ however was used as a biotic control in which the lost of residual hydrocarbon was not significant and could be neglected. Gas chromatographic analysis revealed that most of the aliphatic hydrocarbons extracted from soil have been utilized by augmented $A$. baumannii T30C together with indigenous microorganisms Treatment A, 77\%; Treatment B, 88\% (Figure $3)$.

\section{DISCUSSION}

For soil bioremediation, suitable microorganisms are necessary for an optimal treatment of soils contaminated with petroleum hydrocarbons (Vasudevan and Rajaram, 2001). Mishra et al. (2001a) reported that bioremediation by using microbial inoculants has been a common practice, since it could enhance the rate of biodegradation. On the other hand, environmental factors, such as oxygen level, temperature, nutrients, $\mathrm{pH}$, moisture content, and so forth, may influence the biodegradation of hydrocarbons in soil which have been reported by previous studies. These factors can substantially affect the microbial growth and biodegradation of organic contaminants if not properly governed (Balba et al., 1998). Whereas, Freijer et al. (1996) reported that environmental conditions may influence the mineralization rate of petroleum hydrocarbons and biomass production in determining the successfulness of bioremediation study.

Over the 35 days incubation of $A$. baumannii T30C in 


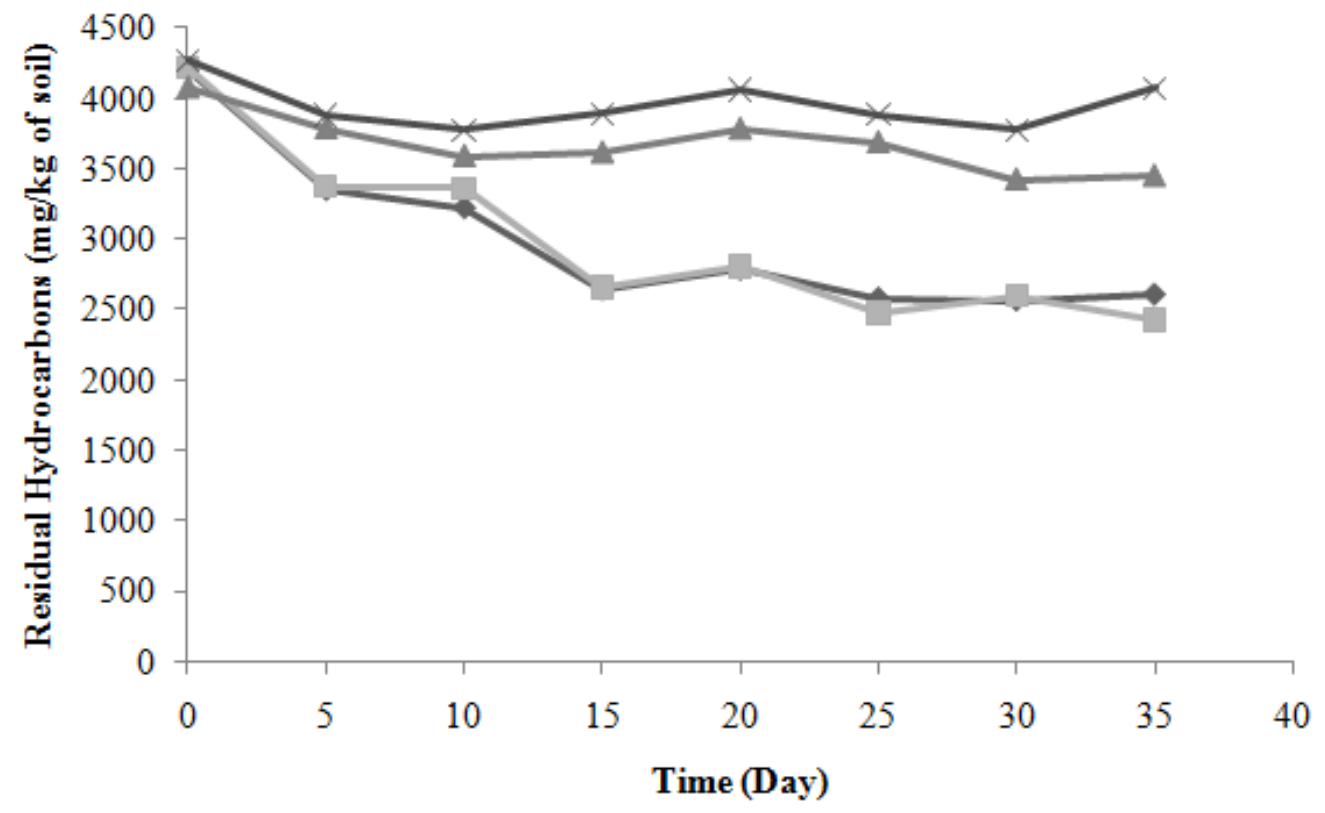

$\leadsto$ Treatment A $\leadsto$ Treatment B $\simeq$ Treatment $\mathrm{C} \leadsto$ Treatment D

Figure 2. Profile of residual hydrocarbons reduction in different treatment of crude oil contaminated soil. For each experimental unit, $10 \%(\mathrm{v} / \mathrm{w})$ of bacterial inoculum which made up of approximately 1 $\times 10^{7}$ colony forming units (cfus) $/ g$ of soil and nutrients from optimized MSM were seeded by maintaining the moisture level of $60 \%$ water holding capacity $(\mathrm{WHC})$ of soil. Treatment A: Soil + bacterial isolate + nutrients; Treatment B: Soil + nutrients; Treatment C: Soil + bacterial isolate; Treatment D: Soil + sterile distilled water (abiotic control).

an aluminium tray, the soil was tilled and sterile distilled water was added to maintain $60 \%$ of $\mathrm{WHC}$ of the soil for every interval of 5 days sampling. Tillage is a mechanical manipulation of soil to improve soil conditions (Sabaté et al., 2004). Molope et al. (1987) reported that tillage may alter physical and chemical properties of soil in such a way that it stimulates microbial activity. Tillage redistributes carbon, nitrogen and water and reduces spatial distribution within the soil (Rhykerd et al., 1999). In general, biodegradation of contaminants in soil systems is optimal at soil moisture content between 30 and $80 \%$ of WHC (Dibble and Bartha, 1979). Bioremediation of hydrocarbon contaminated soils requires careful control of moisture in which $20 \%$ to $60 \%$ water saturation of the soil is optimum (Rosenberg, 1993). Failure to appreciate this fact would lead to the maintenance of excessive water levels in the soil and concomitant reduction in oxygen availability (Baker, 1994). Too much water may cause the soil to become anaerobic as reported by Rosenberg (1993).

The soil selected for this study which was obtained from an oil refinery at Terengganu, Malaysia possessed the $\mathrm{pH}$ value ranging from 6.0 to 7.0 . Biological activity in the soil is greatly affected by the $\mathrm{pH}$, through the availability of nutrients and toxicants and the tolerance of organisms to $\mathrm{pH}$ variations (Eweis et al., 1998).
According to Eweis et al. (1998), the growth of most microorganisms is usually greatest within a $\mathrm{pH}$ range of 6 to 8 , although some fungi have optimal growth regions at $\mathrm{pH}$ levels of less than 5 . Hence, it was expected that $A$. baumannii T30C may exhibit an optimal growth in the soil $\mathrm{pH}$ range of 6.0 to 7.0 .

The soil treatments were conducted in the room temperature of $30 \pm 3^{\circ} \mathrm{C}$ over the 35 days incubation in aluminium trays. Since the optimal growth temperature of A. baumannii $\mathrm{T} 30 \mathrm{C}$ was $37^{\circ} \mathrm{C}$, it was classified as mesophiles. This group of bacteria has optimal growth in the range of 25 to $35^{\circ} \mathrm{C}$ in the soil. Baker (1994) reported that soil temperature influences the extent of biodegradetion in related to microbial activity with rates of metabolic reactions generally increasing with increasing temperature. This fact was also supported by Zekri and Chaalal (2005) who found that increasing the temperature increases the rate of oil degradation by thermophilic bacteria of Bacillus sp.; increasing temperature increases and accelerates the growth of bacteria that resulted in increasing the degradation process of the crude oil at high temperature.

In the present study, the initial indigenous population of oil-degrading bacteria was found to be $2.29 \times 10^{3} \mathrm{CFUs} / \mathrm{g}$ of soil on Treatment $D$ which the control soil sample was not amended with the addition of bacterial inoculum and 


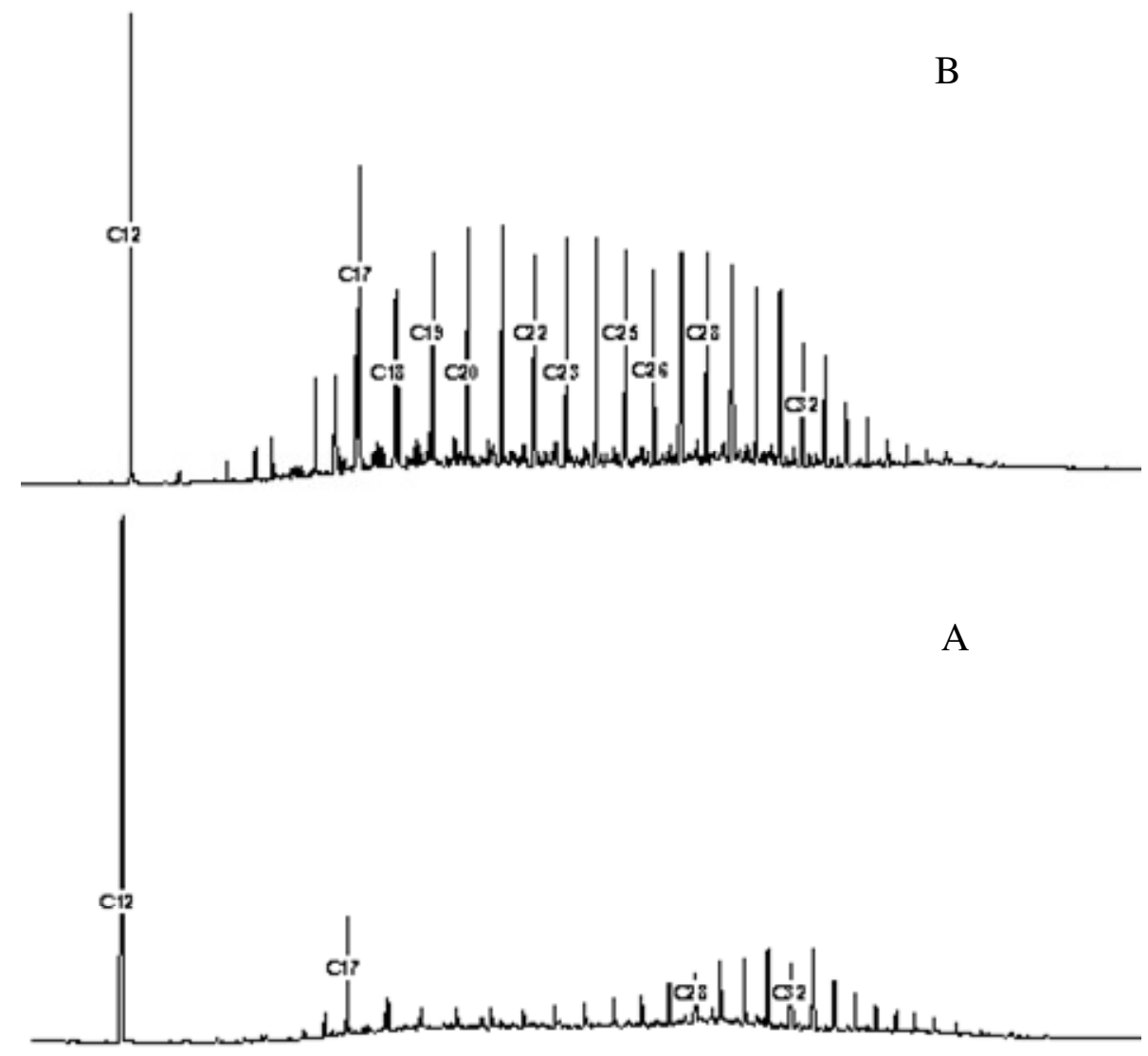

Figure 3. GC-FID profile for Tapis petroleum crude oil in soil bioremediation study. (A) GC profile at Day=35. (B) GC profile at Day=0. IS refers to internal standard.

nutrient. Previous researches reported that bioremediation is negligible if the population of hydrocarbondegrading microorganisms is less than $10^{5} \mathrm{CFUs} / \mathrm{g}$ of soil (Mishra et al., 2001b). The bacterial inoculum needs to be added. However, lower crude oil degradation has been observed as shown on Treatment $C$ which only $A$. baumannii T30C was augmented without addition of nutrient in the oil contaminated soil. This was supported by the result presented on Treatment $A$ (soil + bacterial isolate + nutrients) which the nutrients stimulated the bacterial growth and enhanced biodegradation of crude oil in the soil. This may be attributed to the limitation or deficiencies of nutrient in the soil. Smith et al. (1998) reported that nutrient deficiencies can occur due to the enrichment of carbon sources caused by the pollution events. Addition of nutrients has been reported to enhance the degradation process (Leahy and Colwell, 1990; Barathi and Vasudevan, 2003; Sabaté et al., 2004). Sabaté et al. (2004) reported that the treatment of soil which involved nutrient addition, such as nitrogen and phosphorus sources may lead to a large decrease in total petroleum hydrocarbons by accelerating the growth of microbial population. This was also supported by Leahy and Colwell (1990) in which additional of nitrogen and phosphorus sources are essential for microbial growth. On the other hand, Treatment B (soil + nutrients) showed similar capacity in the degradation of crude oil even though $A$. baumannii T30C was not augmented into the soil. This phenomenon indicated that indigenous microorganisms were capable of degrading crude oil in the soil. Similar result was also observed by Barathi and Vasudevan (2003) who reported that the indigenous microorganisms were capable of degrading alkanes and aromatics existed in crude oil contaminated soil without the addition of bacteria into the soil. Similar findings have been reported by Ghazali et al. (2004) for the dieselpolluted soil that was not inoculated with any microbial consortium which resulted in an increase in numbers of naturally occurring microorganisms in the soil. Venosa et al. (1996) also showed that microbial inoculation did not enhance the removal of hydrocarbons from soil contaminated with crude oil due to other environmental parameters (Dibble and Bartha, 1979).

A few studies have been reported on the effect of bioaugmentation application to the degradation of petroleum hydrocarbons. Hanson et al. (1997) reported 
that an increase in the number of colony forming units and crude oil degradation in crude oil contaminated with Acinetobacter sp. A3, which was capable of degrading Bombay High crude oil, than in unamended soil. On the other hand, higher rate of degradation of alkanes in the soil by Pseudomonas fluorescens was achieved as reported by Barathi and Vasudevan (2003). However, Sabaté et al. (2004) reported that the additional supplementation of nutrients and an inoculation of bacterial consortium had no effect on hydrocarbons degradation.

In terms of crude oil biodegradation study by gravimetric analysis, it is difficult to compare gravimetric data with those reported by other authors. Viñas et al. (2002) reported that there was great variability in the concentration of crude oil used, the type of crude oil, the incubation time and in the methodologies used to quantify degradation. A number of different solvents, fractioning and analytical techniques have been used causing the difficulties in evaluation and comparison of data obtained from research works. Sabaté et al. (2004) reported that the treatment of soil without addition of nutrients showed the reduction of petroleum hydrocarbons about $55 \%$ by gravimetric analysis, whereas the treatment containing nutrients and glucose was the most efficient, which represented a biodegradation of $79 \%$. It showed higher reduction of petroleum crude oil compared with the present study of Treatment A (42\%) and Treatment B $(43 \%)$. As described in other studies, Sabaté et al. (2004) reported that the degradation of organic chemicals in soil usually shows a rapid initial phase of descent followed by a period of little or no change in concentration. This kinetics is known as the "hockey stick" phenomenon (Alexander, 1999). Similar pattern was also found on the reduction of petroleum hydrocarbon in Treatment $A$ and Treatment B. A depletion of nutrients, a decrease of microbial populations, lower availability and higher recalcitrance of residual contaminants explain this kind of dynamic (Heusemann, 1997; Alexander, 1999).

For a soil with high organic-carbon content, the age of the soil was related to the biodegradation. Trindade et al. (2005) reported that the longer the soils are exposed to the environment, the higher would be the resistance of the compounds to be degraded, which would decrease the bioavailability of pollutants to microorganisms. This was attributed to the weathering process including evaporation, dissolution, dispersion, photochemical oxidation, water-oil emulsification, microbial degradation and absorption onto suspended particulate materials, further complicating the already complex oil mixture (Wang and Fingas, 1997). Weathering refers to the result of biological, chemical and physical processes which selectively depletes lower molecular weight $n$-alkanes and volatile aromatic compounds (Readman et al., 1996). The oilcontaminated soils which has been exposed about 6 years to environment has shown a lower biodegradation by gravimetric analysis (Treatment A, 42\%; Treatment B, $43 \%$ ). This could be due to the occurrence of weathering processes causing the lower bioavailability of hydrocarbons.
Nevertheless, a higher degradation of aliphatic hydrocarbons was obtained regarding to chromatogram analysis (Treatment A, 77\%; Treatment B, 88\%). Studies concerning the relationship of chemical composition and biodegradability of crude oil have shown that crude oil containing higher concentration of n-alkanes was found to be more susceptible to microbial attack (Westlake et al., 1974). Of the various petroleum fractions, n-alkanes of intermediate length $\left(\mathrm{C}_{10}-\mathrm{C}_{20}\right)$ are the preferred substrates and tend to be most readily degradable, whereas shorter chain compounds are rather more toxic (Klug and Markovetz, 1971).

\section{Conclusion}

Though the weathering process was responsible for the low levels of biodegradation and residual hydrocarbon removal after 35 days of experiments, the well adapted indigenous microbial population of degraders was responsible for better decontamination results compared with the augmentation of $A$. baumannii T30C into the oilcontaminated soil. Addition of nutrient is mandatory for enhancing bacterial growth and degradation activity. However, in situations where the indigenous population of degraders is small, inoculation with an active strain of bacterial isolate or population of degrading strains is an option for enhancing the biodegradation rate and reducing acclimation period.

\section{ACKNOWLEDGEMENT}

The author would like to thank Petronas Research Sdn. Bhd. and USM for awarding the fellowship grant to the first author.

\section{REFERENCES}

Aldrett S, Bonner JS, Mills MA, Autenrieth RL, Stephens FL (1997). Microbial degradation of crude oil in marine environments tested in a flask experiment. Water Res., 31(11): 2840-2848.

Alef K, Nannipieri P (1995). Methods in applied microbiology and biochemistry. Elsevier Ltd., pp. 576.

Alexander M (1999). Biodegradation and Bioremediation. Academic Press., pp. 453.

Baker KH (1994). Bioremediation of surface and subsurface soils, in: Baker KH, Herson DS (eds), Bioremediation. McGraw-Hill, Inc., pp. 209-259.

Balba MT, Al-Awadhi N, Al-Daher R (1998). Bioremediation of oilcontaminated soil: microbiological methods for feasibility assessment and field evaluation. J. Microbiol. Methods, 32: 155-164.

Barathi S, Vasudevan N (2003). Bioremediation of crude oil contaminated soil by bioaugmentation of Pseudomonas fluorescens NS1. J. Environ. Sci. Health., 38(9): 1857-1866.

Boopathy $R$ (2000). Factors limiting bioremediation technologies. Bioresour. Technol., 74: 63-67.

Das K, Mukherjee K (2007). Crude petroleum-oil biodegradation efficiency of Bacillus subtilis and Pseudomonas aeruginosa strains isolated from a petroleum-oil contaminated soil from North-East India. Bioresour. Technol., 98: 1339-1345.

Dibble JT, Bartha R (1979). Effect of environmental parameters on the 
biodegradation of oil sludge. Appl. Environ. Microbiol., 37(4): 729-739.

Eweis JB, Ergas SJ, Chang DPY, Schroeder ED (1998). Bioremediation Principles. McGraw-Hill Companies, Inc., pp. 296.

Freijer JI, De Jonge H, Bouten W, Verstraten JM (1996). Assessing mineralization rates of petroleum hydrocarbons in soils in relation to environmental factors and experimental scale. Biodegradation, $7(6)$ : 487-500.

Ghazali FM, Zaliha Abdul Rahman RN, Salleh AB, Basri M (2004). Biodegradation of hydrocarbons in soil by microbial consortium. Int. Biodeterior. Biodegradation, 54: 61-67.

Hanson KG, Nigam A, Kapadia M, Desai AJ (1997). Bioremediation of crude oil contamination with Acinetobacter sp. A3. Curr. Microbiol., 35: 191-193.

Heusemann ME (1997). Incomplete hydrocarbon biodegradation in contaminated soil: limitations in bioavailability or inherent recalcitrance? Bioremediat J., 1: 27-39.

Klug MJ, Markovetz K (1971). Utilization of aliphatic hydrocarbons by microorganisms. Adv. Microb. Physiol., 5: 1-39.

Leahy JG, Colwell RR (1990). Microbial degradation of hydrocarbons in the environment. Microbiol. Rev., 54(3): 305-315.

Mishra S, Jyot J, Kuhad RC, Lal B (2001a). In situ bioremediation potential of an oily sludge-degrading bacterial consortium. Curr. Microbiol., 43: 328-335.

Mishra S, Jyot J, Kuhad RC, Lal B (2001b). Evaluation of inoculum addition to stimulate in situ bioremediation of oily-sludgecontaminated soil. Appl. Environ. Microbiol., 67(4): 1675-1681.

Molope MB, Grieve IC, Page ER (1987). Contributions by fungi and bacteria to aggregate stability of cultivated soils. Eur. J. Soil Sci., 38: 71-77.

Rahman KSM, Thahira-Rahman J, Laskhmanaperumalsamy P, Banat IM (2002). Towards efficient crude oil degradation by a mixed bacterial consortium. Bioresour. Technol., 85: 257-261.

Readman JW, Bartocci J, Tolosa I, Fowler SW, Oregioni B, Abdulraheem MY (1996). Recovery of the coastal marine environment in the Gulf following the 1991 war-related oil spills. Mar. Pollut. Bull., 32(6): 493-498.

Rhykerd RL, Crews B, McInnes KJ, Weaver RW (1999). Impact of bulking agents, forced aeration and tillage on remediation of oilcontaminated soil. Bioresour. Technol., 67: 279-285.

Rosenberg E (1993). Exploiting microbial growth on hydrocarbons: new markets. Trends Biotechnol., 11: 419-424.
Sabaté J, Viñas M, Solanas AM (2004). Laboratory-scale bioremediation experiments on hydrocarbon-contaminated soils. Int. Biodeterior. Biodegradation, 54: 19-25.

Sathishkumar M, Binupriya AR, Baik SH, Yun SE (2008). Biodegradation of crude oil by individual bacterial strains and a mixed bacterial consortium isolated from hydrocarbon contaminated areas. Clean, 36(1): 92-96.

Smith VH, Graham DW, Cleland DD (1998). Application of resourceratio theory to hydrocarbon biodegradation. Environ. Sci. Technol., 32: 3386-3395.

Swannell RPJ, Head IM (1994). Bioremediation come of age. Nature, 368: 396-397.

Trindade PVO, Sobral LG, Rizzo ACL, Leite SGF, Soriano AU (2005). Bioremediation of a weathered and a recently oil-contaminated soils from Brazil: A comparison study. Chemosphere, 58: 515-522.

Vasudevan N, Rajaram P (2001). Bioremediation of oil sludgecontaminated soil. Environ. Int., 26: 409-411.

Venosa $A D$, Suidan MT, Wrenn BA, Strohmeier KL, Haines JR, Eberhart BL, King DW, Holder E (1996). Bioremediation of experimental oil spill on the shoreline of Delaware Bay. Environ. Sci. Technol., 30: 1764-1775.

Viñas M, Sabaté J, Solanas AM (2002). Biodegradation of a crude oil by three microbial consortia of different origins and metabolic capabilities. J. Ind. Microbiol. Biotechnol., 28: 252-260.

Vogel TM (1996). Bioaugmentation as a soil bioremediation approach. Curr. Opin. Biotechnol., 7: 311-316.

Wang Z, Fingas M (1997). Developments in the analysis of petroleum hydrocarbons in oils, petroleum products and oil-spilled-related environmental samples by gas chromatography. J. Chromatogr. A, 774: $51-78$

Wang Z, Fingas M, Li K (1994). Fractionation of a light crude oil and identification and quantification of aliphatic, aromatic, and biomarker compounds by GC-FID and GC-MS, Part 1. J. Chromatogr. Sci., 32: 361-366.

Westlake DWSA, Jobson R, Philipe R, Cook FD (1974). Biodegradability and crude oil composition. Can. J. Microbiol., 20: 915-928.

Zekri AY, Chaalal O (2005). Effect of temperature on biodegradation of crude oil. Energy Sources Part A, 27: 233-244. 